Obrazovanje odraslih/Adult Education, ISSN 1512-8784, Broj I - 2 2020., str. 79-I Io

UDK: 316.774: 004.738.5]: 37.04

Pregledni članak/Rewiev paper

Primljeno/Received: 08. 07. 2020.

Prihvaćeno/Accepted: 02. 02. 202 I.

Ivana Sivrić ${ }^{1}$

Maja Pandža Topić

\title{
Virtualni svijet djece i mladih: izazovi na putu odrastanja ${ }^{3}$
}

Sažetak: Mediji odgajaju našu djecu i čine važan dio njihove svakodnevice. Nemoguće je zamisliti život bez prisutnosti medija. Oni su glavni izvor informacija, sadržaja, tema o odgoju, obrazovanju, kulturi, politici, zabavi. Mediji predstavljaju socijalizacijski agens čiji je utjecaj na društvo, djecu i mlade značajan. Slijedom navedenog, trebala bi postojati veća društvena intencija za edukacijom o medijima, medijskom odgoju i obrazovanju. Uloga medijskog odgoja u našim školama još je uvijek nedovoljno iskorištena, često marginalizirana, ali ponekad i neshvaćena kako od strane učitelja, nastavnika, tako i od djece i mladih. Svakodnevno raste broj medijskih, internetskih korisnika, profila na društvenim mrežama, o čemu svjedoče brojna istraživanja, ali nema dovoljno odgoja za medije i odgoja za kritičko mišljenje. Stoga smo u ovom radu nastojali istražiti medijske navike djece i mladih u lokalnoj zajednici, s posebnim osvrtom na vrijeme koje provode na internetu, ponajviše na društvenim mrežama, te da li to vrijeme utječe na njihove svakodnevne interakcije s okolinom, prijateljima, obitelji, a na kraju i na njihov uspjeh u školi. Zanimalo nas je koliko koriste društvene mreže, u kojoj dobi otvaraju profile, te koliko su slobodni u pružanju informacija o sebi i drugima putem medija. Prema onome što su rezultati pokazali, djeca u jako ranoj fazi otvaraju profile na društvenim mrežama i kada za to nisu spremna niti educirana. Također, djeca su veoma otvorena za virtualni svijet komunikacije s osobama koje ne poznaju u stvarnom životu, pa čak i za susrete s nepoznatim osobama, a da pritom nisu svjesna moguće manipulacije, lažnih

\footnotetext{
${ }^{1}$ Doc. dr. sc. Ivana Sivrić, docentica na Studiju novinarstva i odnosa s javnošću Filozofskog fakulteta Sveučilišta u Mostaru; e-mail: ivana.sivric@ff.sum.ba

${ }^{2}$ Maja Pandža Topić, viša asistentica na Studiju psihologije Filozofskog fakulteta Sveučilišta u Mostaru; e-mail: maja.pandža@ff.sum.ba

${ }^{3}$ Rad je nastao u okviru projekta „Sigurnost djece na internetu: digitalne navike, odgoj i zaštita“ koji je uradilo Društvo za medijsku kulturu u Hercegovačko-neretvanskoj županiji, a financiralo Federalno ministarstvo obrazovanja i nauke.
} 
profila, nasilja i sličnog. Postoji jasno iskazana svjesnost kod većine ispitanika o potrebi za medijskim odgojem, bez obzira na razliku u količini vremena koje ispitanici provode na društvenim mrežama i jasno iskazan stav o nužnosti uvođenja medijskog odgoja kao dijela obaveznog obrazovanja u školama.

Ključne riječi: virtualni svijet, medijski odgoj, medijske navike, djeca i mladi, medijska pismenost.

\section{Uvodna razmatranja}

Govor o virtualnom svijetu često se stavlja u opoziciju realnom, što nije posve ispravno, jer koncept virtualnog, u kontekstu novih medija, sve više postaje dio svakodnevnih čovjekovih aktivnosti i navika. Virtualni svijet je figurativan ${ }^{4}$ (Klaić 2004: 425) prostor u kojemu pojedinac može provoditi puno vremena, stvarati odnose, prijateljstva, ugovarati poslove, istraživati i sl. Kako se često u posljednje vrijeme spominje, a i mnoga istraživanja u svijetu i regiji su pokazala, ${ }^{5}$ mladi i djeca jako mnogo vremena provode u virtualnom svijetu. Naš je cilj bio istražiti navike koje djeca i mladi posjeduju i stvaraju kada je u pitanju virtualni svijet interesantan mladima, s posebnim osvrtom na društvene mreže i izazove s kojima se djeca susreću u sazrijevanju i odrastanju u virtualnom svijetu. Većinom su to izazovi koji se odnose na količinu vremena koje djeca i mladi provode s medijima, a koji često idu na uštrb nekih drugih aktivnosti, potom sadržaj kojem su izloženi, kao i izražavanje rizičnih ponašanja na društvenim mrežama i razina empatije i osjetljivosti na nasilje koje se potiče na društvenim mrežama.

Nastojali smo istražiti medijske navike djece i mladih, s posebnim osvrtom navrijeme koje provodes medijima, te da li to vrijeme utječe na njihove svakodnevne interakcije s okolinom, prijateljima, obitelji, a na kraju i na njihov uspjeh u školi. Jednako tako nas je zanimalo kakav je stav ispitanika prema medijskom odgoju i općenito prema uvođenju jednog ovakvog načina obrazovanja u školstvo. Iako medijska pismenost postavlja kritičko pitanje o utjecaju medija i tehnologije, to nije antimedijski pokret. Umjesto toga, predstavlja koaliciju zabrinutih

\footnotetext{
${ }^{4}$ Lat. figura, figuralan - izrečen u slici, koji je izražen preneseno.

${ }^{5}$ Prvenstveno se misli na istraživanje konzorcija EU KIDS ONLINE, koji čine 33 zemlje, a koje (istraživanje) predstavlja svjetski standard praćenja sigurnosti djece na internetu.
} 
pojedinaca, organizacija (nastavnici, vjerske zajednice, zdravstveni radnici, grupe građana, medijskih djelatnika) koji traže načine kako pojasniti ambivalentnu ulogu medija i naučiti pojedinca (djecu i mlade, prije svega) kako medije koristiti za svoje potrebe, a ne da ih mediji dezorijentiraju i s njima manipuliraju.

Istraživanje je pokazalo na čemu u budućnosti trebamo raditi kada su u pitanju edukacije djece o medijima i stjecanje medijskih navika, a sve u svrhu što kvalitetnijeg medijskog odgoja. $\mathrm{Na}$ početku, a prije predstavljanja samog istraživanja, prikazat ćemo što je svrha i cilj medijskog obrazovanja, zašto je medijska pismenost važna u medijskom odgoju djece i mladih.

\section{Što je medijsko obrazovanje i čemu služi?}

Prema UNESCO-ovom shvaćanju, postoje četiri osnovna elementa za proučavanje medijske pismenosti:

- kao instrument za zaštitu djece i maloljetnika

- kao instrument za zaštitu medijskih konzumenata,

- kao preduvjet za građansku participaciju

- kao instrument za premošćivanje digitalnog jaza (Tajić 2013: 40).

$\mathrm{U}$ ovom radu namjera je bila istražiti medijsku pismenost kao instrument za zaštitu djece $i$ maloljetnika, pri čemu smo nastojali pojasniti kako medijskim obrazovanjem možemo stvoriti odgovorniji odnos prema digitalnim tehnologijama, ali i odgoju za kritičko mišljenje. Kada kažemo pismenost, generalno nam pada na pamet elementarna pismenost, ali ona danas nije dovoljna pojedincu za napredak i održivost u suvremenom svijetu i novim trendovima u obrazovanju. Organizacija UNESCO (2004) je dala preporuke za uvođenje novih pismenosti u 21. stoljeću, koje pored osnovne i funkcionalne pismenosti uključuju i informacijsku pismenost, financijsku, računalnu, medijsku, čitalačku pismenost. Sve vrste pismenosti važne su za pojedinca kako bi uspješno funkcionirao u privatnom i profesionalnom smislu u vremenu u kojem živi i radi (cf. Olawale Olaniran 2020: 4). Promatrajući trendove i tehnologiju, društvo koristi različite oblike komunikacije, a time i pismenost postaje višedimenzionalna, multimodalna, ${ }^{6} \mathrm{~s}$ obilježjem transpismenosti, što hoće reći da ima mogućnost

\footnotetext{
${ }^{6}$ Prikaz sadržaja sa slikom, zvukom i videom.
} 
prenošenja komunikacije, informacije i znanja putem različitih formata i medija. Renee Hobbs, tako, navodi nekoliko vrsta suvremenih pismenosti (informacijska i informatička pismenost, vizualna, zdravstvena i emocionalna). Za sve oblike pismenosti navodi da se ne smiju tretirati kao konkurentni pojmovi, već nadopunjujući jedni na druge (cf. Hobbs 2010: 17). Većina teoretičara masovne komunikacije slaže se u tome da su različiti procesi, digitalizacija, promjena u učenju, nove reforme obrazovanja, doveli do potrebe i razmišljanja o uvođenju medijskog odgoja u školski sustav. Postoji više različitih područja, polja i pristupa u proučavanju medijskog odgoja. Pojedine razlike pri uključivanju odgoja za medije u škole nastale su zbog činjenice da države na različite načine vrednuju značenje sistematizacije odgoja za medije u školsku satnicu. Iznimni interes za temu „Mladi i tehnologija“ vidljiv je i na terminološkoj razini prave poplave pojmova koji slikovito ilustriraju uzajamnu povezanost mladih i tehnologije upotrebljavanjem termina poput $Y$ generacije, milenijske ili net generacije, Google generacije, digitalnih urođenika, cyber-djece, kolaborativne generacije (engl. collaboration generation), generacije $\mathrm{M}$ (engl. media generation), generacije $\mathrm{V}$ (engl. virtual generation) ili generacije C (u kojemu C označava engl. termine connected: povezani, creative: kreativni i click: često klikaju mišem). Navedeni pojmovi oblikuju diskurs o mladima i njihovom korištenju računala (Lasić Lazić et al. 2012: 126).

Većina država koje imaju razmjerno razvijen odgoj za medije naglašava prije svega njegovu integraciju u osnovne predmete osnovnoškolskog i srednjoškolskog nastavnog plana, poput materinjeg jezika i socioloških i humanističkih predmeta, a ne toliko oblikovanje specifičnoga predmeta (Zgrabljić i Erjavec 2000: 102103). Francuska je prva zemlja u Europi koja je uvela odgoj za medije u škole, pri čemu je fokus stavljen na filmski odgoj i medijsku kulturu. Danas, zemlje poput Finske medijsku pismenost uče od vrtića do završetka srednje škole. U Finskoj ovaj termin uključuje poticanje transverzalnih kompetencija u pet područja: briga i organizacija svakodnevnog života, učenje i razmišljanje, participacija, višestruka pismenost i kompetencije vezane za informacijske i komunikacijske tehnologije (IKT), kulturna kompetencija. Svrha i smisao tako koncipiranog medijskog obrazovanja jest da se djeca nauče i uključe u komunikaciju posredstvom tehnologije i tako razvijaju svoje nove vještine i kompetencije o uporabi medija i tehnologije u svakodnevnom životu (cf. Dokler 2018). 
Medijska pismenost proučava se i kroz medijsku pedagogiju, znanstvenu disciplinu koja se bavi klasifikacijom medijskog obrazovnog mišljenja u interdisciplinarni - diskusijski kontekst, gdje se uvijek na kraju postavlja pitanje kako konceptualno doskočiti novim praktičnim problemima kojima smo kao medijski konzumenti izloženi (cf. Baacke 2007: 10-15). Novo informacijsko društvo ovu znanstvenu disciplinu stavlja u kontekst medijske etike, ali i medijskog praktičnog diskursa. U središtu medijske pedagogije je i proučavanje medijske kompetencije. Prema Miliši i suradnicima, medijska kompetencije je središnji pojam u medijskoj pedagogiji. Ona podrazumijeva sve sposobnosti koje moraju usvojiti roditelji, djeca i učitelji o uporabi medija, a te sposobnosti se odnose na izgradnju kritičke svijesti s obzirom na izazove novih medija (cf. Miliša et al. 2010: 113-115). Zadaća je medijskog odgoja da se bavi usvajanjem medijske pismenosti i medijskih kompetencija kod djece i mladih. Turčilo smatra da se o medijskoj pismenosti raspravlja kako u akademskom diskursu tako i u široj javnosti. Promatra medijsku pismenost kroz dva ključna pristupa: medijska pismenost kao individualna kompetencija koju je potrebno razvijati od najranije dobi, te medijska pismenost kao društveno neophodna vještina korištenja i kreiranja informacija, koja je preduvjet odgovornih i funkcionalnih medija i društvene komunikacije uopće, a koja se razvija tokom cijeloga života, kroz formalno i neformalno obrazovanje (Turčilo 2020: 192-193). Prema tome, sustavan pristup proučavanju medijske pismenosti ključan je element za stjecanje medijskih kompetencija, ali i preduvjet za rješavanje nejednakosti u tri ključna problema: participacijski rascjep - nejednak pristup prilikama, iskustvima, vještinama i znanju, koji će pripremiti mlade za potpunu participaciju u svijetu sutrašnjice; problem transparentnosti - izazovi s kojima se mladi ljudi suočavaju u učenju kako bi jasno vidjeli načine na koje mediji oblikuju percipiranje svijeta, te etički izazov (Vrkić Dimić 2014: 388). Stoga je intencija ovog rada da se mladi osvijeste o odgovornoj uporabi medija kako bi mogli kontrolirati svoje medijske navike ako one ne korespondiraju s njihovim željama i afinitetima, ali i da posredstvom medija mladi stvaraju kulturološke matrice u svojoj svijesti koje oblikuju njihova razmišljanja, norme, pravila ponašanja u stvarnom životu i svijetu.

U knjizi Superpovezani, američki autor Chayko kaže da ljudi grade svoje društvene procese i okruženja. Zahvaljujući zajedničkim simbolima, kao što su jezik, slika, zvuci, gestovi i avatari, ljudi zamišljaju i kreiraju te prostore (...). 
Simboličke predstave o drugima (misli o njima, slike, fotografije) podsjećaju nas na njih čak i kad nisu fizički uz nas, te i u njihovom odsustvu možemo i dalje održavati međusobne veze (Chayko 2019: 65). Primjer ovakvog korištenja simbola u svrhe prepoznavanja, dijeljenja simbola o osobnim preferencijama (glazba, hrana, zabava, kultura, politika) koristimo u promociji i predstavljanju sebe i svojih navika drugim ljudima unutar svoje "društvene zajednice“ koji nas karakteriziraju. Liberalna ideologija shvaća društvo bitno drugačije od durkheimovskog pristupa ${ }^{7}$ kao mrežu dobrovoljnih razmjena između samostalnih pojedinaca koji imaju svoje interese i motive. Društvene grupe međusobno se povezuju polazeći od svojih posebnih interesa i želja, što stvara kulturni i politički pluralizam (Šućur 2004: 50). Umreženo, društveno djelovanje utječe na svakodnevno ponašanje djece i mladih i njihovu interakciju s okolinom. Koliko im u tom sazrijevanju, odgovornijem pristupu i razvoju kritičke evaluacije može pomoći odgoj za medije i medijska pismenost pitanje je koje možemo najprije individualno promatrati. To podrazumijeva, prije svega, odgovor na pitanje o pojedincu, spolu, njegovom odgoju, obrazovanju, socijalnoj integraciji u društvu, uporabi medija i slično. Stoga, utjecaj nije jednostavno prepoznati i identificirati. Kompleksan je i višeznačan pristup proučavanju medijskog utjecaja, a potom i pismenosti i medijskog odgoja.

Oprečna su mišljenja o tome što bi bio medijski utjecaj i kako ga možemo definirati. U knjizi Mediji i mladi autora Andya Rudodocka teoretičari Gunter (2008) i Sundar (2009) iznose mišljenje da istraživanje utjecaja u konvencionalnom smislu podrazumijeva eksperimente i ankete kojima se generiraju kvantitativni podaci da bi se saznalo na koji način izlaganje medijskom sadržaju utječe na mišljenje i djelovanje (Ruddock 2015: 43). Ovim istraživanjem smo nastojali istražiti kako se medijske navike stvaraju i posredstvom medijskog utjecaja prelijevaju na svakodnevicu i ponašanje djece i mladih. Međutim, ako globalno promatramo medijski utjecaj prema gore navedenom stavu, nalaže nam se pitanje koliko je medijski utjecaj kategorija proučavanja pristupa ili kategorija proučavanja izloženosti?

\footnotetext{
7 Prema shvaćanju E. Durkheima (1858-1917) društvene činjenice se trebaju proučavati kao prirodne datosti, isključujući iz njih svaki subjektivni moment. Predstavnik je kolektivno-psihološke orijentacije, jer smatra da je pojedinac posljedica društvene diferencijacije koja proizlazi iz podjele rada.
} 
Prije svega, mladima je pristup medijima potreban radi obrazovanja, komunikacije, ${ }^{8}$ ali nemaju svi jednak pristup ni jednake uvjete za korištenje medija. Drugo, u društvima gdje se jasno primijeti zasićenost medijskim porukama postoji problem medijske ambivalentnosti i ciljeva medijske industrije, $s$ jedne strane da pruže informacije i obrazuju javnost, a s druge strane da zadovolje ekonomsku održivost (Ruddock 2015: 43-53).

Polazimo od pretpostavke da se utjecaj medija reflektira kroz prizmu izloženosti. Tako definirajući medijski utjecaj, postavili smo si zadatak da istražimo medijske učinke na navike i ponašanje djece i mladih. Istražujući utjecaj i medijske navike mladih i djece, želja nam je bila prikazati kako mediji utječu na mlade osobe u svakodnevnim uvjetima, polazeći od pretpostavke da su utjecaji društvene prirode; potiču ih društvene prilike, mediji, kultura, politika, obrazovanje. Doba mladosti je doba u kojem osoba gradi i pronalazi svoj osobni identitet. Odvajamo se od roditeljskog utjecaja, težnjom k autonomiji i samoopredjeljenju, a istovremeno nastojimo i da se više oslonimo na svoju grupu vršnjaka (Katzer 2019: 243). Jednako kao i u stvarnom svijetu, djeca formiraju svoje identitete i u virtualnom svijetu, bilo da konzumiraju medijske sadržaje bilo da ih sami proizvode. Zanimao nas je sadržaj kojem su potencijalno izloženi, bilo da se radi o tzv. darknetu' ${ }^{9}$ (cf. Bartlett 2016: 13) ili internetskim trolovima, ${ }^{10}$ pornografiji, cybernasilju, internetskim hejterima, ${ }^{11}$ virtualnom vršnjačkom nasilju, nasilju u videoigrama i slično.

\footnotetext{
${ }^{8}$ Suvremeni pristup obrazovanju podrazumijeva uporabu digitalnih tehnologija i novih medija u nastavi. Djeca rođena u 21. stoljeću razlikuju se od drugih generacija djece po drugačijem načinu življenja i djelovanja. To podrazumijeva uporabu računala, pametnih telefona, tableta, virtualne mreže, društvene komunikacije. Način na koji primaju informacije veže se i uz način obrade tih informacija. Djeca su sklona multimodalnom sadržaju i brzoj pretrazi i dobivanju povratne informacije o svom znanju. (Vidi e-Škole.hr. Integracija digitalne tehnologije u učenju i poučavanju i poslovanje škole, 2018.)

9 Jamie Barlett, istraživač radikalnih društvenih i političkih online pokreta, autor knjige Darknet u digitalnom podzemlju, navodi da termin predstavlja šifrirani svijet skrivenih servisa gdje korisnike nitko ne može identificirati, ali da je to ujedno i šokantni, kontroverzni i uznemirujući kutak interneta dostupan samo dobro upućenima, ali otvoren za pretraživanje svima.

${ }^{10}$ Engl. troll-computing slang - osoba koja u virtualnom prostoru (internetske grupe, forumi, blogovi) namjerno podnosi zapaljive, podrugljive i uvredljive poruke kako bi remetila tijek rasprave u svrhu ostvarivanja određenih interesa.

11 Osobe koje u online prostoru nastoje povrijediti i omalovažiti druge.
} 


\section{Metode istraživanja, odabir uzorka i postupak}

Istraživanje je provedeno u Hercegovačko-neretvanskom kantonu/županiji u 2018/2019. godini. Rađeno je u sklopu projekta „Sigurnost djece na internetu: digitalne navike, odgoj i zaštita “. ${ }^{12}$ Korištena metoda istraživanja je anketiranje, odnosno tehnika anketnog upitnika (postupak prikupljanja podataka putem pismenog odgovaranja ispitanika na pitanja koja su im prezentirana u pismenoj formi). Pitanja su numerički postavljena i analizirana. Odgovori su postavljeni abecednim redom. Korištena su zatvorena pitanja (pitanja s ponuđenim odgovorima), te jedno otvoreno pitanje (pitanja sa slobodnim odgovorom), koje se odnosilo na osobni stav ispitanika o medijskom odgoju. $U$ istraživanju je sudjelovalo ukupno 279 učenika (49,1\% učenici; 50,9 \% učenice) iz četiri osnovne škole. Učenici su pohađali 4. (46,2 \%) i 7. (53,8 \%) razred osnovne škole. Među njima, najčešće zastupljeni su bili učenici izvrsnog uspjeha $(54,1 \%)$, nakon čega slijede vrlo dobri $(41,9 \%)$ i učenici dobrog uspjeha $(4 \%)$.

\section{Cilj istraživanja i hipoteze}

Cilj istraživanja bio je utvrditi navike korištenja društvenih mreža i ponašanja na internetu među učenicima osnovnoškolskog uzrasta, te ukazati na potrebu za medijskim odgojem u školama.

U ovom istraživanju medije se, u svakodnevnom životu djece i mladih, promatra kroz društvene mreže ili, kako ih još nazivamo, društvene medije. Oni predstavljaju internetski prostor, čija je primarna svrha da služi za međusobno povezivanje svojih korisnika. Društvene mreže, pored komunikacije, koja predstavlja osnovnu svrhu povezivanja korisnika u ovom virtualnom prostoru, služe i u druge svrhe, poput marketinga i promocije raznih usluga, ali nudi i mnogo otvorenog prostora za istraživanje i poznavanje novih spoznaja i pojedinaca, što zahtijeva dodatna znanja i oprez pri korištenju društvenih mreža. Ako znamo iz ranijih istraživanja da su djeca i mladi u velikoj mjeri korisnici društvenih mreža, onda je namjera ovog istraživanja da analiziramo utjecaj društvenih mreža iz perspektive izloženosti komunikaciji s nepoznatim osobama, virtualnom

\footnotetext{
${ }^{12}$ Istraživanje je provedeno prije početka pandemije Covida-19, stoga nisu rađene analize i interpretacije podataka s obzirom na promjene u vezi s medijskim navikama djece i mladih pod utjecajem Covida-19.
} 
vršnjačkom nasilju i slično i kakve se medijske navike stvaraju kod djece i mladih, bilo da konzumiraju medijske sadržaje bilo da ih sami proizvode.

Navike korištenja medija operacionalizirane su kroz sljedeće indikatore:

- Vrijeme (u tijeku dana) provedeno na internetu

- Incidencija otvorenih profila na društvenim mrežama (Facebook, Instagram) na ispitanom uzorku

- Najčešće objavljivani sadržaji na profilima društvenih mreža.

Navike ponašanja na internetu operacionalizirane su kroz sljedeće indikatore:

- Rizična ponašanja na društvenim mrežama

- Razina empatije i osjetljivost na nasilje na društvenim mrežama.

Pored navedenih indikatora, zadatak ovog istraživanja je bio ispitati stav učenika o potrebi za medijskim odgojem u školama.

Kao nezavisne varijable $\mathrm{u}$ istraživanju su se javili: spol, uzrast učenika (razred koji pohađa), vrijeme provedeno u korištenju interneta, školski uspjeh učenika i preferencije u provođenju slobodnog vremena. Dobiveni podaci o navikama korištenja medija dalje su komparirani u odnosu na navedene varijable.

Prije ispitivanja postavljena je glavna hipoteza koja glasi: Navike djece $i$ mladih osnovnoškolskog uzrasta u korištenju društvenih mreža imaju efekt na ponašanje korisnika i svakodnevnu interakciju s okolinom i vršnjacima te ukazuju na potrebu uvodenja medijskog odgoja kao dijela obaveznog odgoja u školama. Pod pojmom ponašanje podrazumijevaju se ishodi učenja (školski uspjeh) dok se pojam interakcija odnosi na rizična ponašanja na društvenim mrežama.

Ostale specifične hipoteze bile su:

$\mathrm{H}_{1}$ : Većinu slobodnog vremena djeca i mladi provode uz medije.

$\mathrm{H}_{2}$ : Većina ispitane djece i mladih ima otvorene profile na nekim od društvenih mreža (Instagram, Facebook).

$\mathrm{H}_{3}$ : Djeca i mladi skloni su izražavanju rizičnog ponašanja u virtualnom svijetu, što je u vezi s količinom vremena koje provode uz medije kao i sadržajem koji promatraju.

H4: Veća količina vremena koje djeca provedu koristeći medije dovodi do slabijeg školskog uspjeha.

H5: Mladi su svjesni važnosti medijskog odgoja u formalnom obrazovanju. 


\section{Statističke analize}

Za statističku analizu podataka korišteni su programski sustavi SPSS for Windows (inačica 21.0, SPSS Inc, Chicago, Illinois, SAD). Prikazani su parametri deskriptivne statistike za varijable - aritmetička sredina i standardna devijacija te frekvencije i postoci, ovisno o vrsti varijable. U svrhu odgovora na istraživačke zadatke korišten je hi-kvadrat test, a pri manjku očekivane frekvencije Fisherov egzaktni test.

Statistička značajnost analiziranih rezultata postavljena je na $\mathrm{p} \leq 0.05$.

\section{Rezultati}

\section{Vrijeme provedeno na internetu}

Općenito, učenici najčešće provode po pola ili jedan sat dnevno na internetu (28\%), nakon čega slijedi skupina koja provodi po tri (21\%) ili četiri i više (20\%) sati na internetu.

ne koristim internet $\square$ pola sata $\square$ sat $\square$ sata $\quad 4$ i više sati

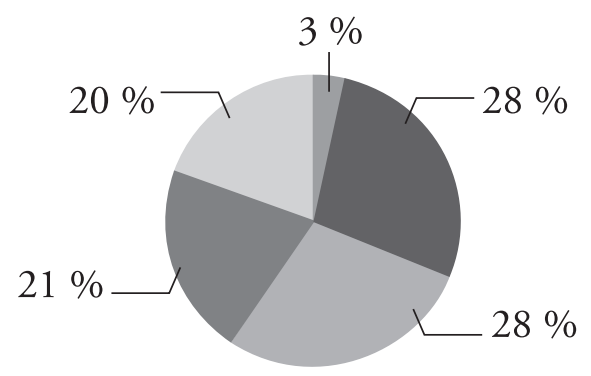

Grafički prikaz 1: Vrijeme provedeno na internetu

- Vrijeme provedeno na internetu, $s$ obzirom na spol učenika

Usporedbom raspodjele vremena provedenog na internetu, $s$ obzirom na spol učenika, utvrđene su razlike u količini vremena koju djevojčice i dječaci provedu na ovom mediju, odnosno: utvrđene su razlike u vremenu provedenom na internetu s obzirom na spol. Ova razlika je najveća za kategorije od pola sata te četiri i više sati provedenih na internetu (Grafički prikaz 2). Djevojčice češće 
navode da provode po pola sata dnevno $(35,2 \%)$ na internetu, u odnosu na $20,4 \%$ dječaka. S druge strane, dječaci češće $(25,5 \%)$ provode na internetu po četiri sata i više, u odnosu na 13,4 \% djevojčica.

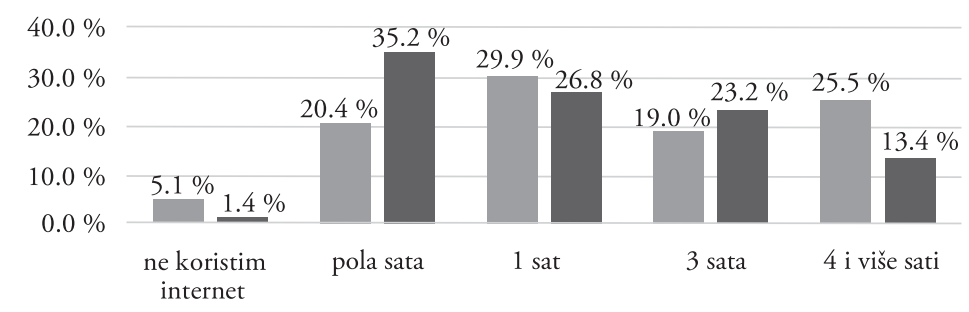

Vrijeme provedeno na internetu

$\square \square \check{Z}$

Grafički prikaz 2: Vrijeme provedeno na internetu, s obzirom na spol

\section{- Vrijeme provedeno na internetu, s obzirom na uzrast učenika}

Usporedba vremena provedenog na internetu, s obzirom na uzrast učenika, pokazala je razlike u navikama učenika 4. i 7. razreda. Uočljivo je da mlađi učenici ponajviše provode pola sata dnevno na internetu (44,2 \%; Grafički prikaz 3) u usporedbi s $14 \%$ učenika 7. razreda u ovoj kategoriji. Istovremeno, stariji učenici provode dulje vrijeme na internetu - njih $26,7 \%$ provede po tri, a preko $30 \%$ i četiri i više sati. S druge strane, učenici 4. razreda rijetko $(5,4 \%)$ provode duže od četiri sata na internetu.

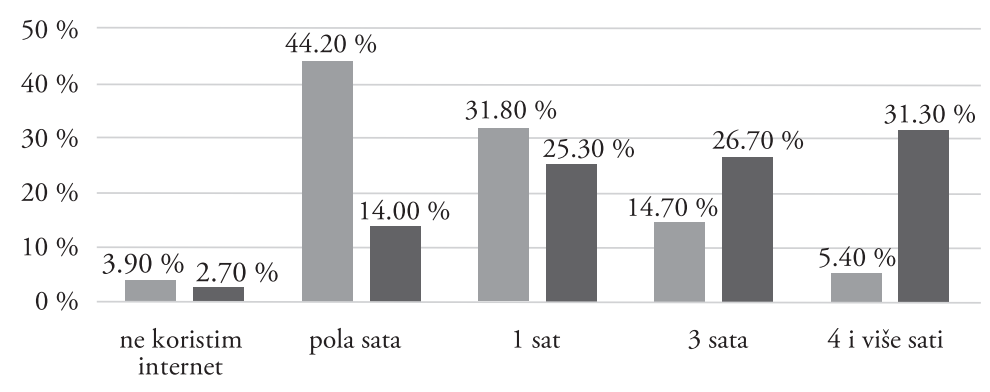

Vrijeme provedeno na internetu

4. razred $\quad$ 7. razred

Grafički prikaz 3: Vrijeme provedeno na internetu, s obzirom na uzrast 


\section{Zastupljenost profila na društvenim mrežama (Facebook i Instagram)}

Pregledom odgovora učenika, može se zaključiti da postoje dvije izjednačene skupine učenika s obzirom na posjedovanje profila na Facebooku (Grafički prikaz 4). Drugim riječima, oko 50 \% učenika ima otvoren profil na Facebooku. $S$ druge strane, u nešto nižoj je zastupljenosti broj profila na Instagramu - oko $43 \%$ ispitanih ima otvoren profil na ovoj društvenoj mreži.

Korisno je spomenuti da je na pitanje otvorenog tipa o mogućim drugim profilima na drugim društvenim mrežama, oko $10 \%$ učenika navelo da ima barem još jedan profil na drugim mrežama. Najčešće su navođeni Viber i YouTube, kao mreže na kojima učenici, pored ispitanih, imaju dodatne otvorene profile.

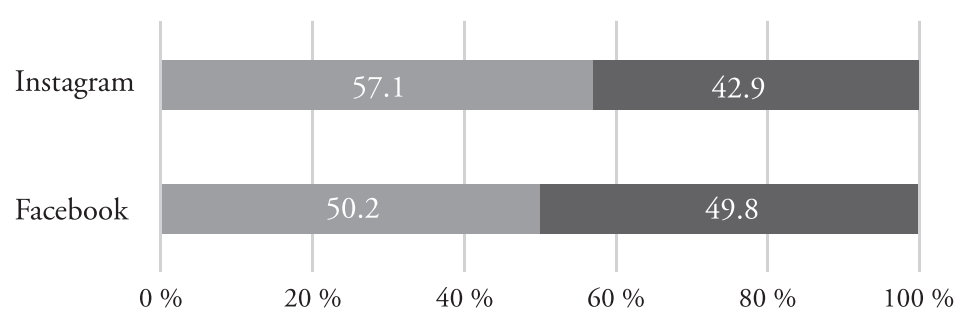

Profil na društvenoj mreži

Nema $\quad$ Ima

Grafički prikaz 4: Učestalost otvorenih profila na društvenim mrežama

- Zastupljenost otvorenih profila (Facebook, Instagram) s obzirom na spol

Kako bi se analizirale moguće razlike u zastupljenosti otvorenih profila na Facebooku i Instagramu među učenicima i učenicama, testirale su se razlike u odgovorima učenika. Kada je riječ o Facebooku, čini se da dječaci $(57,7$ \%) imaju nešto češće otvoren profil na ovoj društvenoj mreži u odnosu na djevojčice $(42,3 \%)$. Na Instagramu je podjednaka zastupljenost profila među učenicima i učenicama - nešto više od $40 \%$ učenika obiju skupina ima otvoren profil na ovoj mreži (Grafički prikaz 5). 


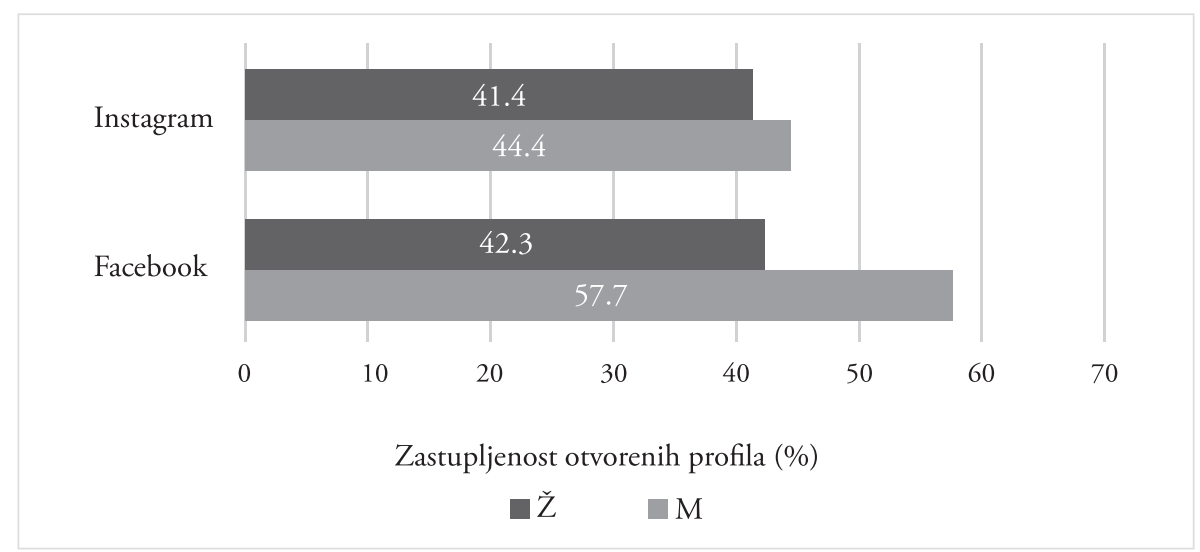

Grafički prikaz 5: Zastupljenost otvorenih profila na Facebooku i Instagramu, s obzirom na spol učenika

- Zastupljenost otvorenih profila (Facebook, Instagram) s obzirom na uzrast Kako bi se usporedile moguće razlike u zastupljenosti otvorenih profila, s obzirom na druge relevantne karakteristike učenika, testirane su razlike u zastupljenosti, uzevši u obzir uzrast učenika (4. i 7. razred osnovne škole). Za slučaj obiju društvenih mreža (Facebook i Instagram) utvrđena je češća zastupljenost otvorenih profila na starijem uzrastu učenika (Grafički prikaz 6). Više od dvije trećine učenika 7. razreda ima vlastiti profil na Facebooku i Instagramu. Kada je riječ o učenicima 4. razreda, nešto više od $10 \%$ ima profil na Instagramu, dok je zastupljenost vlastitih profila na Facebooku nešto češća (30,2 \%).

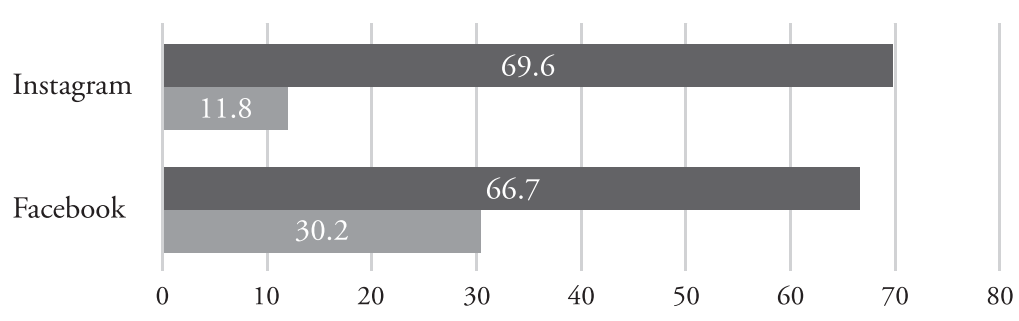

Zastupljenost otvorenih profila (\%)

- $7 . \quad 4$.

Grafički prikaz 6: Zastupljenost otvorenih profila na Facebooku i Instagramu, $s$ obzirom na uzrast učenika 


\section{- Prosječna dob otvaranja profila, $s$ obzirom na spol}

Uzevši u obzir da je prethodni nalaz pokazao relativno zastupljen broj profila na društvenim mrežama među učenicima 4. razreda, zanimalo nas je u kojoj su dobi učenici otvorili profile koje trenutačno imaju. U prosjeku, prema ispitanom uzorku, učenici otvaraju profile na društvenim mrežama nešto prije 10. godine $(\mathrm{M}=9,85$; Grafički prikaz 7). Uzevši u obzir odgovore ispitanih učenika, minimalna dob otvaranja profila na nekoj od društvenih mreža je osam, dok je najviša utvrđena (na skupini učenika 7. razreda) 13 godina starosti.

Navedeni nalazi i prosječna dob vrijede i za učenike i učenice, s obzirom na to da nisu utvrđene razlike u dobi otvaranja profila s obzirom na spol.

\begin{tabular}{c|c|c|c|c|c}
\hline Spol & $\mathrm{M}$ & $\mathrm{SD}$ & $\mathrm{t}$ & $\mathrm{df}$ & $\mathrm{p}$ \\
\hline $\mathrm{M}$ & 9,71 & 1,385 & & 182 & $>0.05$ \\
\hdashline$\check{Z}$ & 10 & 1,447 & -1.367 & & \\
\hline
\end{tabular}

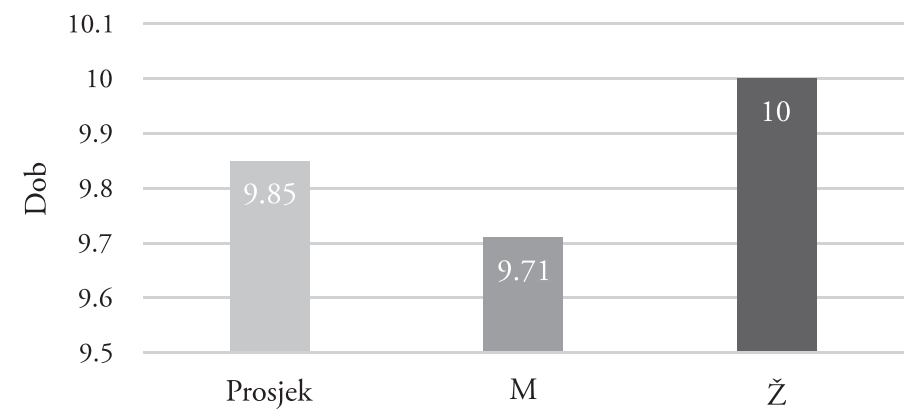

Grafički prikaz 7: Prosječna dob otvaranja profila na društvenim mrežama, s obzirom na spol

\section{Najčešće objavljivani sadržaji na profilima društvenib mreža}

Pregledom učestalosti odgovora učenika o najčešće objavljivanim sadržajima na profilima društvenih mreža (Grafički prikaz 8) može se zaključiti da učenici najčešće dijele svoje privatne fotografije (47\%), nakon čega trećina njih (33\%) objavljuje različite linkove. U nešto nižoj zastupljenosti (15\%), objavljuju se značajni životni događaji, dok rijetki učenici (5\%) navode da na svojim profilima najčešće objavljuju značajne životne događaje. 


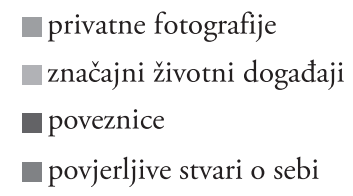

privatne fotografije

značajni životni događaji

povjerljive stvari o sebi

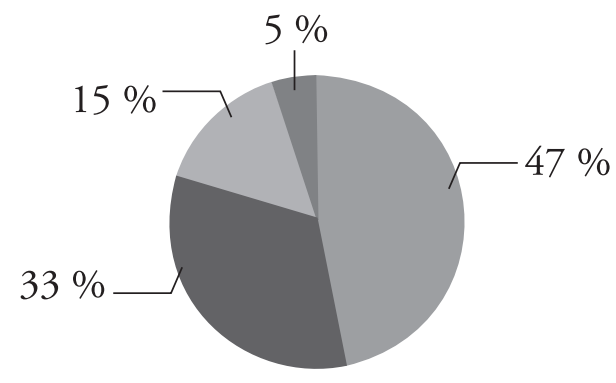

Grafički prikaz 8: Najčešće objavljivani sadržaji na profilima društvenih mreža

- Najčešće objavljivani sadržaji na profilima društvenih mreža, $s$ obzirom na spol

Usporedbom najčešće objavljivanih sadržaja na profilima društvenih mreža $s$ obzirom na spol, utvrđene su značajne razlike u navikama objavljivanja među učenicima i učenicama (Grafički prikaz 9). U usporedbi s dječacima (39 \%), djevojčice su sklonije objavljivati privatne fotografije (55,4\%), kao i značajnije životne događaje (20,8 \% djevojčica vs. $9,5 \%$ dječaka). S druge strane, dječaci nešto češće objavljuju poveznice na profilima (44,8\%), u odnosu na djevojčice $(19,8 \%)$. Kada je riječ o objavljivanjima povjerljivih stvari o sebi, čini se da nema velike razlike među dječacima $(6,7 \%)$ i djevojčicama (4\%).

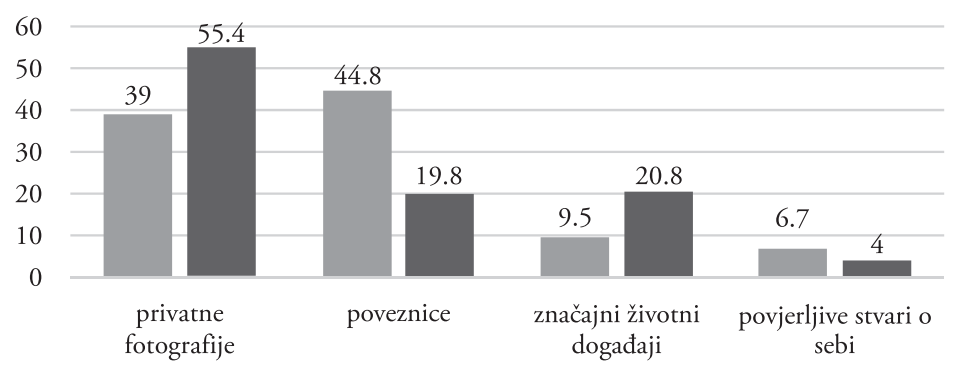

Najčešće objavljivani sadržaji

$\square \square \check{Z}$

Grafički prikaz 9: Najčešće objavljivani sadržaji, s obzirom na spol 
- Najčešće objavljivani sadržaji na profilima društvenih mreža, $s$ obzirom na uzrast

S obzirom na uzrast (Grafički prikaz 10), nisu utvrđene značajne razlike u navikama objavljivanja različitih sadržaja na profilima društvenih mreža između učenika 4. i 7. razreda. Potvrđen je raniji nalaz (Grafički prikaz 8), u kojem su najčešće objavljivane privatne fotografije, a najrjeđe povjerljive stvari o sebi.

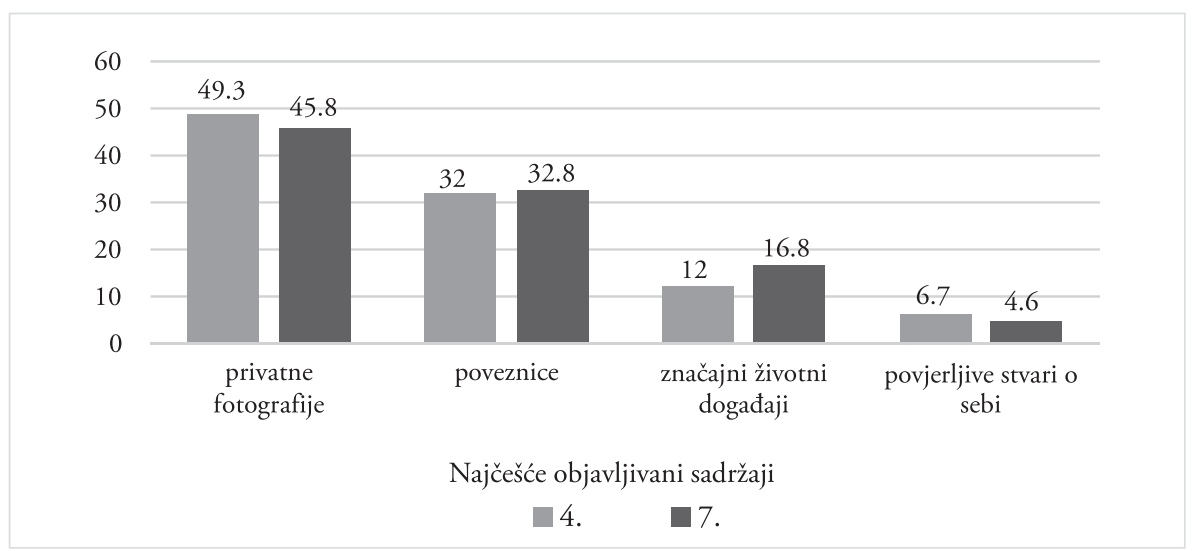

Grafički prikaz 10: Najčešće objavljivani sadržaji, s obzirom na uzrast

\section{Rizična ponašanja na društvenim mrežama - spremnost na komunikaciju i upoznavanje s odraslim osobama}

Pregled učestalosti rizičnih ponašanja na društvenim mrežama pokazuje da su učenici davali svoje odgovore o spremnosti na komunikaciju putem društvenih mreža s nepoznatim osobama, kao i na mogućnost upoznavanja osoba s kojima su stupile u komunikaciju preko društvenih mreža (Grafički prikaz 11). Prema odgovorima učenika, gotovo $31 \%$ učenika se dopisivalo/komuniciralo s nepoznatim osobama na društvenim mrežama, dok je nešto manje od $23 \%$ odgovorilo da bi bili spremni sastati se uživo s osobom koju su „upoznali“ na društvenim mrežama. 


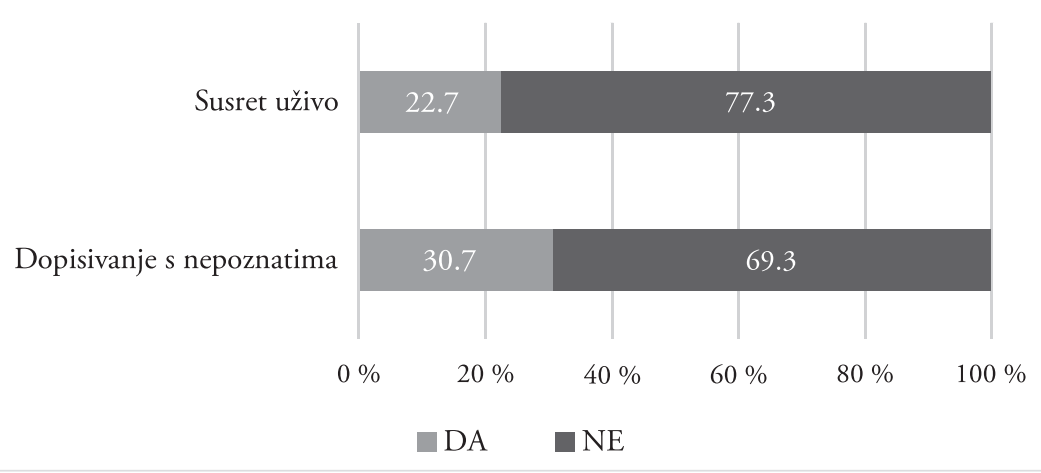

Grafički prikaz 11: Spremnost na komunikaciju i upoznavanje s nepoznatim odraslim osobama

\section{- Rizična ponašanja na društvenim mrežama, s obzirom na spol}

\section{Dopisivanje s nepoznatima, $s$ obzirom na spol}

Usporedbom odgovora učenika i učenica o iskustvu dopisivanja s nepoznatim osobama preko interneta (Grafički prikaz 12) utvrđene su razlike u iskustvima, s obzirom na spol. Dječaci su se nešto češće dopisivali s nepoznatima (37,6 \%) u odnosu na $(24,1 \%)$ djevojčica. Utvrđene su statistički značajne razlike.

\begin{tabular}{|c|c|c|c|c|c|}
\hline & & & \multicolumn{2}{|c|}{ Dopisivanje s nepoznatima } & \multirow{2}{*}{ Total } \\
\hline & & & $\mathrm{da}$ & ne & \\
\hline \multirow{4}{*}{ Spol } & $\mathrm{M}$ & f & 50 & 83 & 133 \\
\hline & & $\%$ & $37,6 \%$ & $62,4 \%$ & $100,0 \%$ \\
\hline & 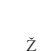 & $\mathrm{f}$ & 33 & 104 & 137 \\
\hline & & $\%$ & $24,1 \%$ & $75,9 \%$ & $100,0 \%$ \\
\hline \multirow{2}{*}{ Total } & & $f$ & 83 & 187 & 270 \\
\hline & & $\%$ & $30,7 \%$ & $69,3 \%$ & $100,0 \%$ \\
\hline \multicolumn{6}{|c|}{$\chi^{2}=5.782 ; \mathrm{df}=1, \mathrm{p}<0.05$} \\
\hline
\end{tabular}




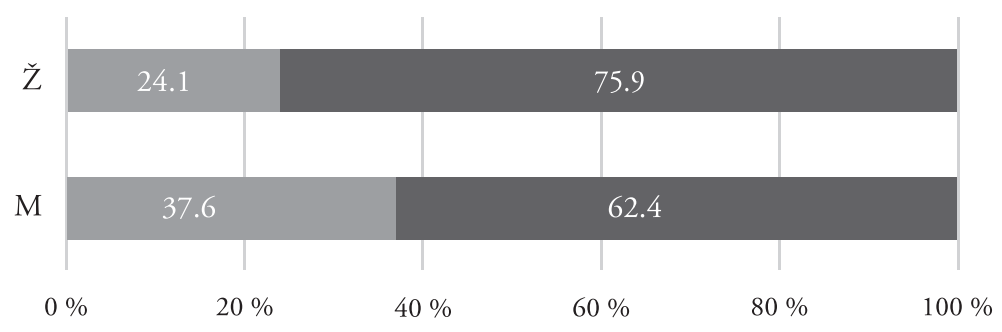

Dopisivanje s nepoznatima

$\square \mathrm{DA}$

Grafički prikaz 12: Dopisivanje s nepoznatima, s obzirom na spol

\section{Susret uživo s nepoznatima}

Kada je riječ o spremnosti na susret uživo s nepoznatima, s kojima su stupili u kontakt preko profila društvenih mreža (Grafički prikaz 12), ne postoje razlike u učestalosti odgovora dječaka i djevojčica. Dok je oko $9 \%$ više dječaka nego djevojčica (27,2 \% vs. 18,3 \%) spremno upoznati nepoznatu osobu, koju su upoznali online, ova razlika nije dovoljno velika da bi bila proglašena značajnom.

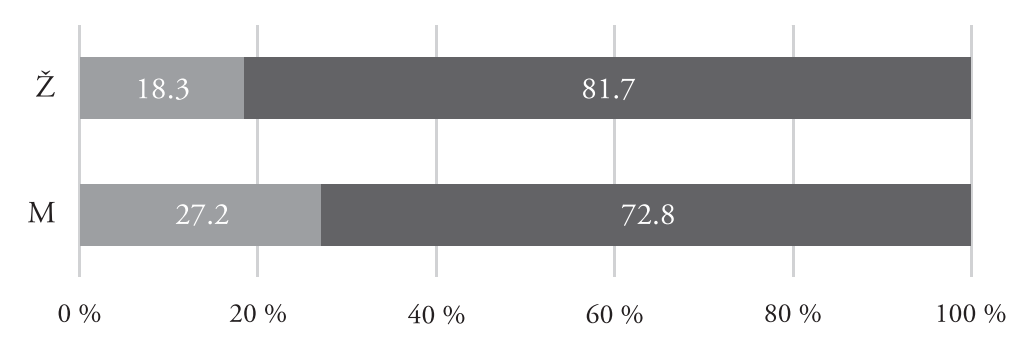

Upoznavanje s nepoznatima

$\square \mathrm{DA}$

Grafički prikaz 13: Upoznavanje s nepoznatima, s obzirom na spol 


\section{- Rizična ponašanja na društvenim mrežama, s obzirom na uzrast}

\section{Dopisivanje $s$ nepoznatima}

Pregledom odgovora učenika 4. i 7. razreda o iskustvu dopisivanja s nepoznatima (Grafički prikaz 14) nisu utvrđene značajne razlike u učestalosti odgovora - u obje skupine, oko $30 \%$ anketiranih $(28,1 \%$ učenika 4 . razreda i 32,9 \% učenika 7. razreda) imalo je iskustvo dopisivanja s nepoznatima.

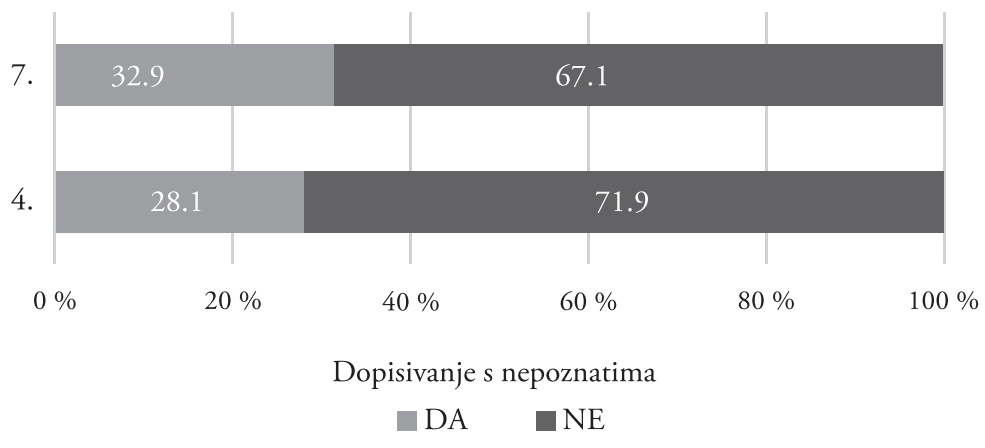

Grafički prikaz 14: Dopisivanje s nepoznatima, s obzirom na uzrast

\section{Upoznavanje s nepoznatima}

Kada je riječ o spremnosti upoznavanja s nepoznatim osobama, s kojima su inicijalno stupili u kontakt preko društvenih mreža, postoje razlike u odgovorima učenika 4. i 7. razreda. Generalno, stariji učenici su češće spremni upoznati nepoznate osobe $(32,9 \%)$ u odnosu na $10,9 \%$ učenika 4. razreda (Grafički prikaz 15).

7.

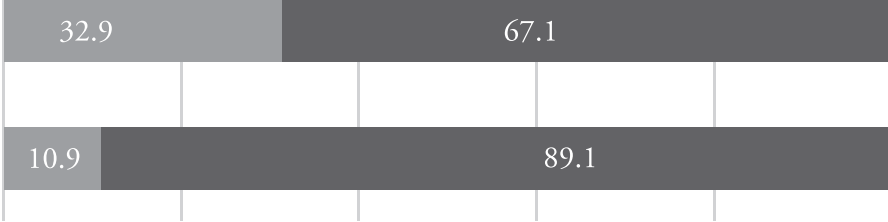

$\begin{array}{llllll}0 \% & 20 \% & 40 \% & 60 \% & 80 \% & 100 \%\end{array}$

Upoznavanje s nepoznatima

$\square \mathrm{DA} \quad \mathrm{NE}$

Grafički prikaz 15: Upoznavanje s nepoznatima, s obzirom na uzrast 


\section{Razina empatije i osjetljivosti na nasilje na društvenim mrežama}

Među istraživačkim ciljevima, ispitana su i iskustva učenika s nasilnim interakcijama na društvenim mrežama. Općenito, nešto manje od 40 \% učenika je od prijatelja ili poznanika primilo uvredljivu poruku ili komentar putem interneta. Istovremeno, $15 \%$ anketiranih učenika priznaje da su i sami slali uvredljive poruke drugima, u odnosu na $67 \%$ ispitanih koji tvrde da putem društvenih mreža nikad nisu slali poruke ovakvog oblika. Također, $20 \%$ anketiranih je navelo da su iskusili širenje neistina o njima putem društvenih mreža.

\section{Odnos vremena provedenog na internetu i školskog uspjeha}

Analizom odnosa vremena provedenog na internetu i školskog uspjeha (Grafički prikaz 16), utvrđene su značajne razlike između ovih dviju varijabli. Kada se analizira učestalost odličnog uspjeha s obzirom na vrijeme provedeno na internetu tijekom dana, kod odličnih učenika uočeno je da provode manje vremena u korištenju interneta. Konkretnije, 36,5 \% učenika koji provode pola sata na internetu prolaze odličnim uspjehom, u odnosu na $32,4 \%$ onih koji budu po sat vremena, 18,9\% koji provedu 3 sata te $12,2 \%$ učenika koji provode 4 i više sati na internetu. Također, suprotan obrazac učestalosti je utvrđen za zastupljenost vrlo dobrih učenika i vremena provedenog na internetu - što je više vremena provedeno na internetu, veća je zastupljenost vrlo dobrih učenika u takvim kategorijama. Drugim riječima, najmanje je učenika vrlo dobrog uspjeha, koji provode po pola sata $(20,7 \%)$ ili sat vremena $(21,6 \%)$, dok je nešto više vrlo dobrih $(26,1 \%)$ koji provode po 3 sata na internetu. Najviše je učenika vrlo dobrog uspjeha u kategoriji koja provodi po 4 i više sati dnevno na internetu $(31,5 \%)$.

Kada je riječ o usporedbi učestalosti učenika dobrog uspjeha s obzirom na vrijeme provedeno na internetu, nije moguć zaključak o određenom obrascu odgovora, s obzirom na to da tek $3,4 \%$ učenika od ukupnog uzorka prolazi dobrim uspjehom. 


\begin{tabular}{|c|c|c|c|c|c|}
\hline Vrijeme & & \multicolumn{3}{|c|}{ Školski uspjeh } & Total \\
\hline \multirow{2}{*}{ pola sata } & $\mathrm{f}$ & 1 & 23 & 54 & 78 \\
\hline & $\%$ & $11,1 \%$ & $20,7 \%$ & $36,5 \%$ & $29,1 \%$ \\
\hline \multirow{2}{*}{1 sat } & f & 5 & 24 & 48 & 77 \\
\hline & $\%$ & $55,6 \%$ & $21,6 \%$ & $32,4 \%$ & $28,7 \%$ \\
\hline \multirow{2}{*}{3 sata } & $\mathrm{f}$ & 2 & 29 & 28 & 59 \\
\hline & $\%$ & $22,2 \%$ & $26,1 \%$ & $18,9 \%$ & $22,0 \%$ \\
\hline \multirow{2}{*}{4 i više sati } & $\mathrm{f}$ & 1 & 35 & 18 & 54 \\
\hline & $\%$ & $11,1 \%$ & $31,5 \%$ & $12,2 \%$ & $20,1 \%$ \\
\hline \multirow{2}{*}{ Total } & $\mathrm{f}$ & 9 & 111 & 148 & 268 \\
\hline & $\%$ & $3,4 \%$ & $41,4 \%$ & $55,2 \%$ & $100,0 \%$ \\
\hline \multicolumn{6}{|c|}{$\chi^{2}=25.050 ; \mathrm{df}=6, \mathrm{p}<0.01$} \\
\hline
\end{tabular}

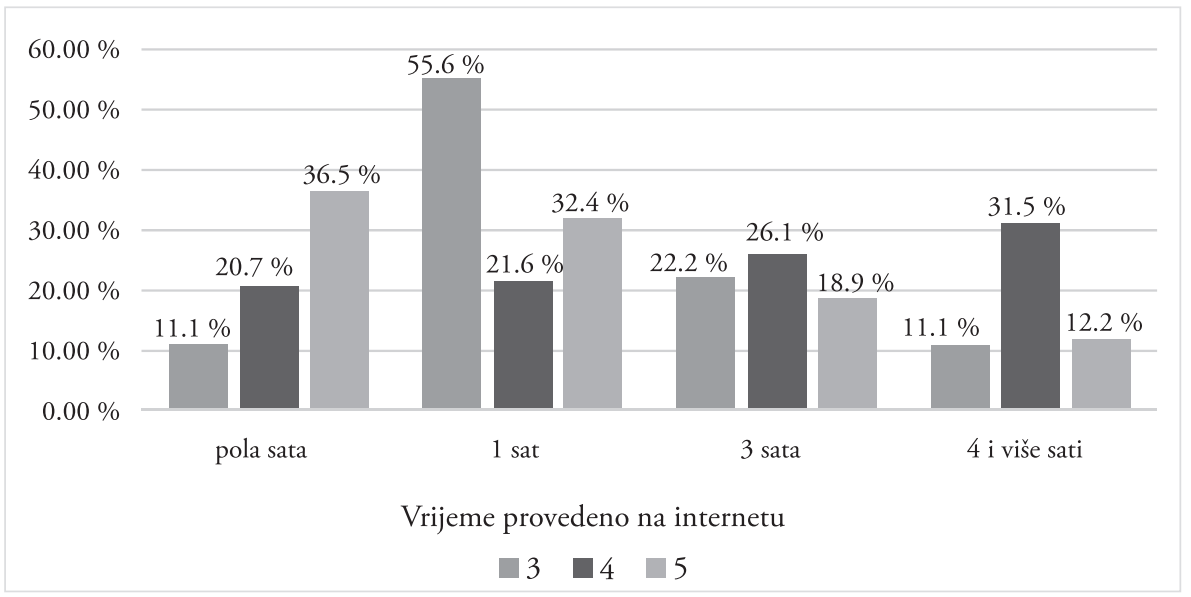

Grafički prikaz 16: Odnos vremena provedenog na internetu i školskog uspjeha 


\section{Odnos vremena provedenog na internetu i školskog uspjeha - pregled prema spolu}

U svrhu detaljnijeg pregleda odnosa vremena provedenog na internetu i školskog uspjeha, posebno je analiziran odnos za podskupinu dječaka (Grafički prikaz 17) i djevojčica (Grafički prikaz 18). Također, izuzeta je manja skupina učenika dobrog uspjeha, u svrhu mogućnosti provedbe statističkih testova unutar navedenih podskupina.

$\mathrm{Na}$ podskupini dječaka, utvrđene su značajne razlike između vrlo dobrih i odličnih učenika s obzirom na vrijeme koje provode na internetu. Generalno, vrlo dobri učenici se najčešće nalaze u kategoriji koja provodi 4 i više sati na internetu $(37,8 \%)$ u odnosu na najrjeđu skupinu vrlo dobrih učenika $(14,9 \%)$ koja provodi po pola sata na internetu. $S$ druge strane, odlični učenici najčešće pripadaju kategoriji koja provede 1 sat na internetu (40,8 \%) nakon čega slijedi podskupina koja je na internetu tek po pola sata $(32,7 \%)$. Najrjeđa skupina odličnih učenika pripada kategoriji koja provodi 4 i više sati na internetu $(12,2 \%)$. Zaključno, utvrđeni su suprotni obrasci odnosa vremena provedenog na internetu i zastupljenosti vrlo dobrih i odličnih učenika za podskupinu dječaka.

\begin{tabular}{|c|c|c|c|c|}
\hline \multicolumn{2}{|l|}{ Vrijeme } & \multicolumn{2}{|c|}{ Školski uspjeh } & Total \\
\hline pola sata & $\begin{array}{l}\mathrm{f} \\
\%\end{array}$ & $\begin{array}{c}11 \\
14,9 \%\end{array}$ & $\begin{array}{c}16 \\
32,7 \%\end{array}$ & $\begin{array}{c}27 \\
22,0 \%\end{array}$ \\
\hline 1 sat & $\begin{array}{l}\mathrm{f} \\
\%\end{array}$ & $\begin{array}{c}17 \\
23,0 \%\end{array}$ & $\begin{array}{c}20 \\
40,8 \%\end{array}$ & $\begin{array}{c}37 \\
30,1 \%\end{array}$ \\
\hline 3 sata & $\begin{array}{l}\mathrm{f} \\
\%\end{array}$ & $\begin{array}{c}18 \\
24,3 \%\end{array}$ & $\begin{array}{c}7 \\
14,3 \%\end{array}$ & $\begin{array}{c}25 \\
20,3 \%\end{array}$ \\
\hline 4 i više sati & $\begin{array}{l}\mathrm{f} \\
\%\end{array}$ & $\begin{array}{c}28 \\
37,8 \%\end{array}$ & $\begin{array}{c}6 \\
12,2 \%\end{array}$ & $\begin{array}{c}34 \\
27,6 \%\end{array}$ \\
\hline Total & $\begin{array}{l}\mathrm{f} \\
\%\end{array}$ & $\begin{array}{c}74 \\
100,0 \%\end{array}$ & $\begin{array}{c}49 \\
100,0 \%\end{array}$ & $\begin{array}{c}123 \\
100,00 \%\end{array}$ \\
\hline & & $\chi^{2}=15$ & 0.01 & \\
\hline
\end{tabular}




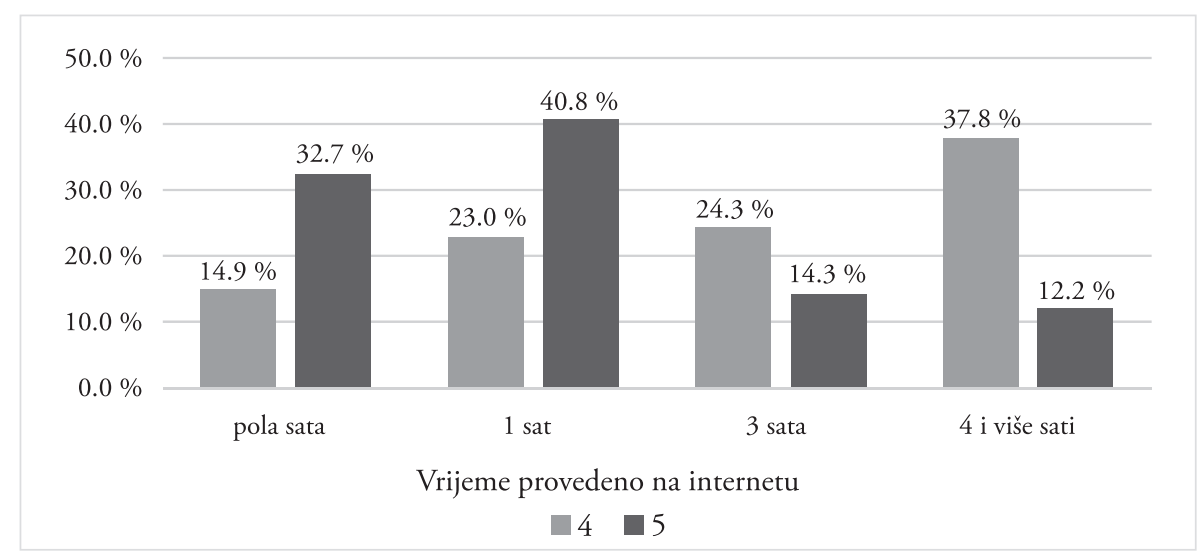

Grafički prikaz 17: Odnos vremena provedenog na internetu i školskog uspjeha (dječaci)

Usporedbom odgovora djevojčica o vremenu provedenom na internetu i školskom uspjehu (vrlo dobri i odlični) nisu utvrđene značajne razlike između ove podskupine djevojčica. Općenito, neovisno o školskom uspjehu, djevojčice najčešće navode da provode po pola sata na internetu (36,8 \%) u odnosu na $14 \%$ najrjeđe zastupljenih, koje provode po 4 i više sati na internetu.

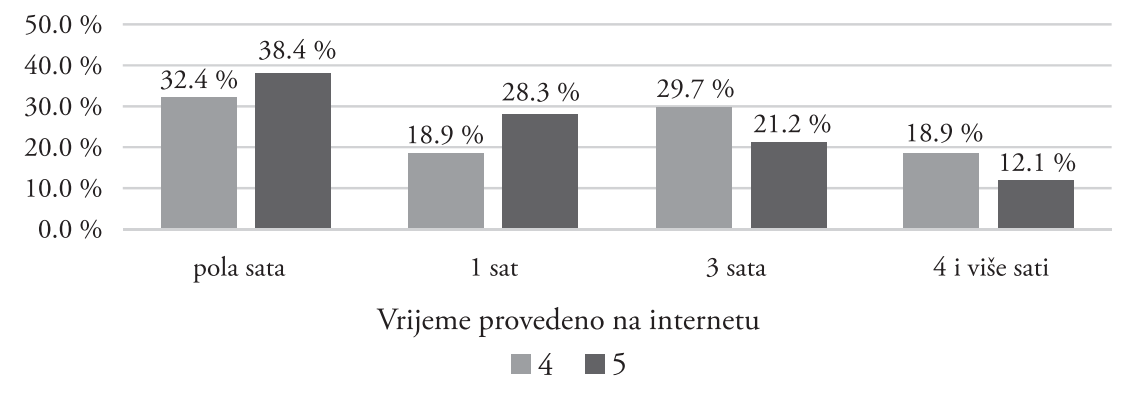

Grafički prikaz 18: Odnos vremena provedenog na internetu i školskog uspjeha (djevojčice) 


\section{Odnos vremena provedenog na internetu i preferencije provođenja slobodnog vremena}

Pregledom preferencija provođenja slobodnog vremena (Grafički prikaz 19) može se zaključiti da gotovo dvije trećine ispitanih najviše voli provoditi vrijeme s prijateljima, nakon čega slijedi niža zastupljenost onih koji slobodno vrijeme provode na YouTubeu (13\%) ili dopisujući se s prijateljima na mobitelu (10\%) te $s$ članovima obitelji (9\%) ili gledajući filmove (5\%). Zanemariv je postotak onih koji vrijeme najradije provode u školi (3\%). U kasnijoj analizi, opisana skupina od $3 \%$ je izuzeta u usporedbama.

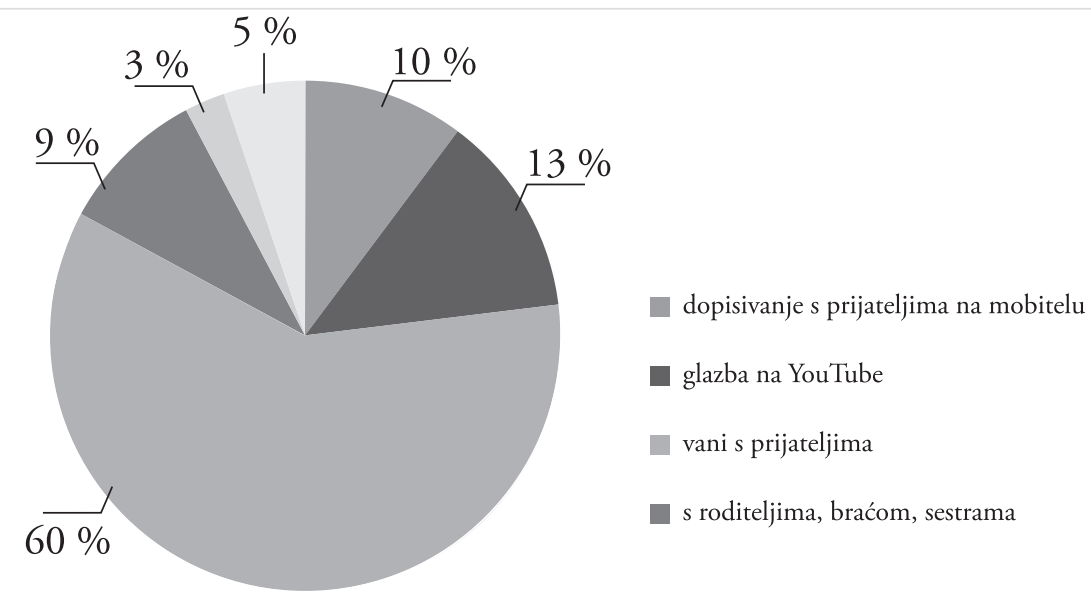

Grafički prikaz 19: Preferencija provođenja slobodnog vremena

Analizom odnosa preferencija provođenja slobodnog vremena i vremena provedenog na internetu utvrđene su značajne razlike u obrascima odgovora učenika (Grafički prikaz 20). U skupini koja provodi po pola sata na internetu ujedno su i najčešće zastupljeni oni koji najradije provode vrijeme $s$ članovima obitelji $(42,3 \%)$. Nasuprot tomu, učenici koji najviše vremena provode na internetu ( 4 i više sati) najradije provode vrijeme na medijima vezanim uz internet - dopisujući se s drugima (32,1\%), slušajući glazbu (34,3\%) i gledajući filmove $(30,8 \%)$. Sličan obrazac je uočen i među učenicima koji provode relativno mnogo vremena na internetu (3 sata), koji preferiraju provesti vrijeme dopisujući se $s$ drugima $(28,6 \%)$, gledajući filmove $(24,1 \%)$, ali i vani s prijateljima $(30,8 \%)$. 
Skupina koja provodi jedan sat dnevno na internetu također preferira i biti vani s prijateljima (32,3 \%) i s obitelji (30,8 \%), ali i slušajući glazbu na YouTubeu $(36,8 \%)$.

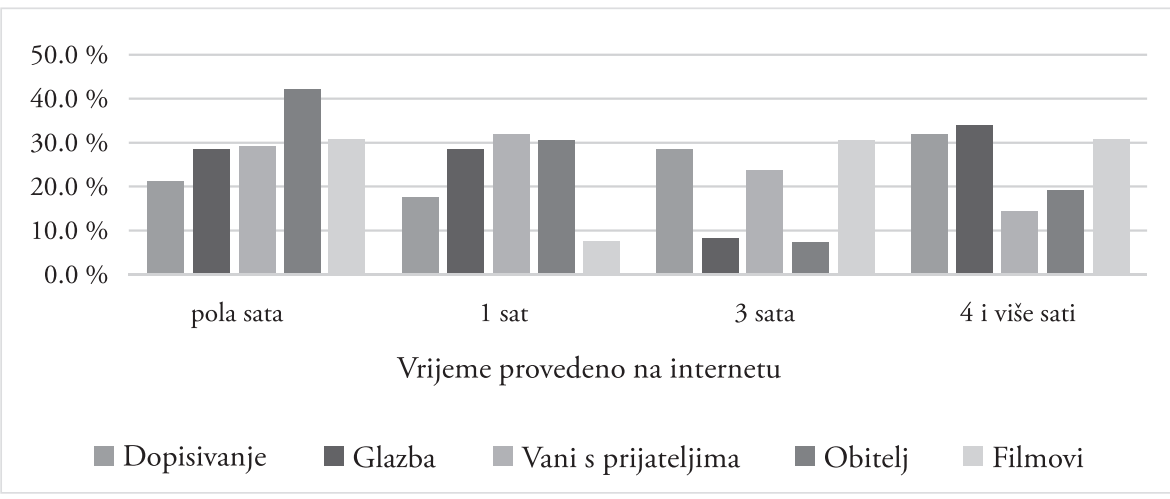

Grafički prikaz 20: Odnos vremena provedenog na internetu i preferencija provođenja slobodnog vremena

\section{Svjesnost o nužnosti medijskog odgoja}

Ispitivanjem stavova učenika o nužnosti medijskog odgoja u školama konstatirano je da se dvije trećine ispitanih slaže da bi medijski odgoj trebao biti dio obaveznog obrazovanja u školama (Grafički prikaz 21), dok $11 \%$ imaju negativan stav, a $26 \%$ nije sigurno je li medijski odgoj potreban.

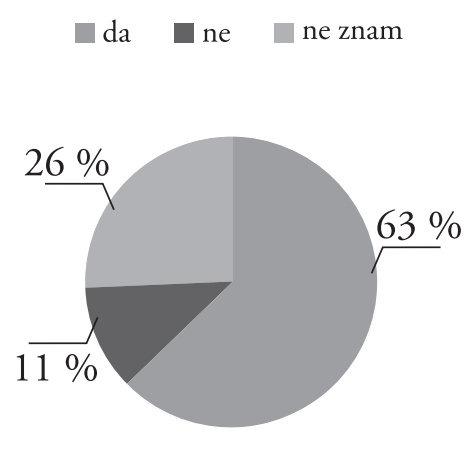

Grafički prikaz 21: Svjesnost o nužnosti medijskog odgoja u školama 
Usporedbom stavova o nužnosti medijskog odgoja u odnosu na vrijeme provedeno na internetu (Grafički prikaz 22) nisu utvrđene razlike u učestalosti odgovora između ovih dviju varijabli. Stoga, kao i u osnovnim analizama (Grafički prikaz 21), potvrđeni su raniji odgovori ispitanih o stavu prema medijskom odgoju, bez razlika u odgovorima učenika koji provode različite količine vremena na internetu.

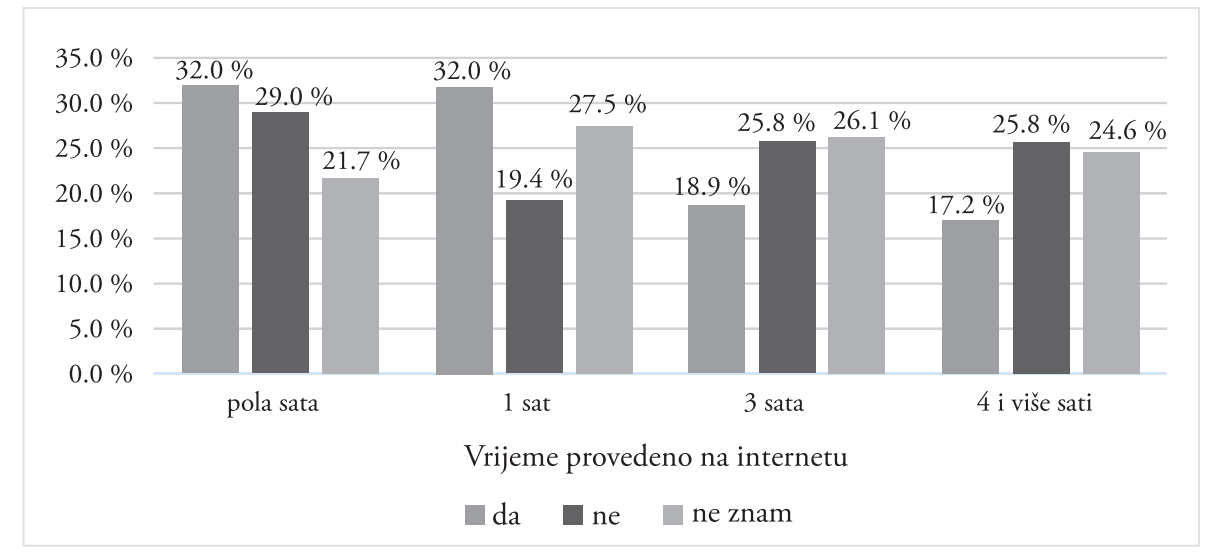

Grafički prikaz 22: Odnos stava o nužnosti medijskog odgoja i vremena provedenog na internetu

\section{Analiza i interpretacija dobivenih rezultata}

Analiza rezultata pokazuje da su djeca i mladi u ranoj fazi razvoja vješti u uporabi tehnologija i medija. Većina ispitanih samostalno je otvorila profile na društvenim platformama (najčešće Facebook - 49,8 \% i Instagram - 42,9 \%). Podaci pokazuju da je prosječna dob kada su djeca otvorila profile 10 godina, što upućuje da za takve odluke nisu niti zrela niti educirana. Naime, oni najčešće objavljuju svoje privatne fotografije i poveznice o interesnim i interesantnim temama, te o značajnim događajima iz svog života, a na kraju najmanje povjerljive stvari o sebi (iako ovdje nije jasno definirano što predstavljaju povjerljive stvari, a što privatne fotografije koje, prema njihovom shvaćanju, ne spadaju u tu kategoriju). ${ }^{13} \mathrm{Iz}$ navedenog se može zaključiti kako djeca i mladi ne razumiju jasno što je privatnost, zakon

\footnotetext{
13 Postoje značajne razlike u navikama objavljivanja među učenicima i učenicama. U usporedbi s dječacima (39 \%), djevojčice su sklonije objavljivati privatne fotografije, dok dječaci nešto češće objavljuju poveznice (44,8 \%).
} 
o privatnosti, zaštita podataka, kao ni koje su moguće manipulacije i sankcije. Mladi su vrlo fleksibilni i otvoreni i kada je riječ o komunikaciji s drugima, a koje su upoznali putem društvenih mreža. Provedeno istraživanje pokazalo je da postoji statistički značajna povezanost provedenog vremena u virtualnom okruženju i rizičnog ponašanja kod tih ispitanika. Prema rezultatima istraživanja $30,7 \%$ ispitanika je imalo priliku dopisivati se $s$ nepoznatim osobama, dok bi se njih 22,7 \% susrelo uživo s osobama koje su upoznali putem društvene mreže. ${ }^{14}$ Komparacijom prema spolu, podaci nam govore da su dječaci (i u jednoj i drugoj starosnoj skupini) više otvoreni za online komunikaciju od djevojčica, ali da i jedni i drugi s vremenom, kako odrastaju, ne postaju oprezniji i odgovorniji, naprotiv, oni su puno opušteniji u izražavanju navedenih rizičnih ponašanja. U isto vrijeme je proturječno da pored toga što su putem medija fleksibilniji i opušteniji prema nepoznatom, oni su, u 39 \% slučajeva, doživjeli nasilje u medijima, primanje uvredljivih poruka od vršnjaka posredstvom medija, a njih čak $20 \%$ je navelo da su i sami širili neistine i laži o drugima putem medija i društvenih platformi.

Još jedan zadatak u istraživanju bio je usmjeren na prikaz odnosa vremena provedenog na internetu sa školskim uspjehom učenika i preferencijama provođenja slobodnog vremena.

Rezultati su pokazali da veća količina vremena koje djeca provedu koristeći medije dovodi do slabijeg školskog uspjeha. Postoje značajna odstupanja kod usporedbe uzorka prema spolu. Dok kod djevojčica nije jasno izražena, kod dječaka je kategorija uspješnosti u školi dosta izražena kod onih koji dnevno provedu četiri i više sati na internetu. Također, ispitan je i stav učenika o nužnosti medijskog odgoja. Prema ispitivanju stava učenika o nužnosti medijskog odgoja u školama, njih čak 63 \% je odgovorilo da bi se odgoj za medije i odgoj s medijima morao nalaziti kao obavezan predmet u školskim propisima i praksi. U skladu s preferencijama provođenja slobodnog vremena, jasan nam je takav stav mladih. Još uvijek je socijalna interakcija, igra na otvorenom s prijateljima, obitelj za njih primarni socijalizacijski agens, kako je pokazalo istraživanje. Stoga bi naša nastojanja trebala biti usmjerena ka jačanju uloge obitelji, prijatelja, škole u društvu kako ne bismo primarni socijalizacijski agens zamijenili sekundarnim i time pomogli određenim medijima, medijskim platformama da „sahrane društvenost“

\footnotetext{
${ }^{14}$ Slično istraživanje provedeno je u Hrvatskoj gdje su rezultati pokazali da se $17,1 \%$ djece na internetu dopisivalo s nepoznatim osobama, dok bi njih 11,8 \% otišlo na sastanak s nepoznatom osobom koju su upoznali na internetu. Publikacija i projekt pod nazivom: EU Kids Online. Zagreb. Dostupno na: https://www.djecamedija.org/eu-kids-online/ (22. 6. 2020.)
} 
a od ljudi stvore „umrežene usamljenike“ (cf. Miliša 2016). Zahvaljujući novim i perspektivnim tehnologijama mijenjaju se (fizički i figurativno) izgled učionice (uporaba digitalnih medija u nastavi), igre (uporaba virtualnih igara), druženje (prelazak komunikacije iz stvarnog svijeta u virtualni). Tek treba svatko za sebe odlučiti do koje mjere će dozvoliti da fizički svijet zamijeni virtualnim i obratno. $\mathrm{Ne}$ možemo zanemariti niti determinirati digitalni razvoj, već se moramo razvijati usporedo s njim. Zgrabljić Rotar navodi da mediji nisu ni dobri ni loši, mogu biti poticajni u kulturnom napretku, ali i frustrirajući u smislu potrošnje, komercijalizacije, natjecanja s tržištem (cf. Zgrabljić Rotar 2007: 72). U tom smislu imaju kontrolno-manipulativnu ulogu u razvoju djece i mladih. Na nama kao roditeljima, odgajateljima a na njima kao konzumentima je da procjenjujemo kako ćemo koristiti medije, odnosno koliko smo educirani za uporabu medija i svih dostupnih tehnologija. 


\section{Zaključak}

Imajući u vidu da je Bosna i Hercegovina još 2003. godine dobila status kandidata za EU, ona treba i mora uskladiti svoje politike obrazovanja prema standardima i $\mathrm{u}$ integraciji s ciljevima Europske unije.

Prema tome, Bosna i Hercegovina kao članica Vijeća Europe obvezna je poštivati njihove standarde, pa tako i izvještavati o stupnju i razvoju medijske pismenosti na ovim terenima. To je naša misija i zadaća. U brojnim europskim zemljama, ministarstva obrazovanja i kulture nadležna su za promociju i razvoj strategije medijske pismenosti. Kod nas je naglasak na regulatorna tijela i civilni sektor. Rezultati brojnih inozemnih i domaćih istraživanja pokazuju da djeca koriste medijske i audiovizualne sadržaje bez nadzora ili s minimalnim nadzorom odgajatelja i roditelja. Stoga, medijska pismenost predstavlja ključnu kompetenciju u razvoju kritičke svijesti, vještina i alata za uporabu medija i medijskih sadržaja. Odgoj za medijsku pismenost predstavlja najbolji način prevencije i zaštite mladih od potencijalno štetnih medijskih sadržaja, ali i prevencije za zdrav i kvalitetan razvoj mlade osobe.

Pored formalnog obrazovnog sustava, najjaču inicijativu u proaktivnom stavu prema medijskoj pismenosti pružaju i dalje civilna udruženja u BiH, ali za razliku od ranije, sada u koordinaciji s Regulatornom agencijom za komunikaciju. Veoma je važno da se umrežavanjem i sinergijom civilnih društava, istraživačkih organizacija, fakulteta, škola, medija, regulatornog tijela, pomiču granice i radi na sustavnom pristupu i edukaciji bosanskohercegovačkih građana o medijskoj pismenosti. Time se stvara put za napredak, kad će i nadležne institucije prepoznati važnost ovog programa/projekta da u konačnici, a po uzoru na druge razvijene zemlje (Finska, Švedska, Norveška, Australija, Njemačka, Slovenija) dobijemo priliku da unutar obrazovnog sustava svakodnevno educiramo djecu i mlade o medijskoj pismenosti i odgoju za medije u 21. stoljeću. 


\title{
Virtual World of Children and Young People: Challenges on Road to Adulthood
}

\begin{abstract}
The media raises our children and form an important part of their daily lives. It is impossible to imagine life without the presence of the media. They are the main source of information, content, and topics on upbringing, education, culture, politics, and entertainment. The media are a socializing agent which impact on society, children and youth is significant. Accordingly, there should be a greater social intention for media education and training. The role of media education in our schools is still underused, often marginalized and sometimes misunderstood by both teachers, preschool teachers, children and young people. The number of media, internet users and profiles on social networks is growing every day, as evidenced by numerous studies, but there is not enough education for the media nor education for critical thinking. Therefore, in this paper we tried to explore the media habits of children and youth in the local community, with special reference to the time that they spent on the Internet, mostly on social networks, and whether the time spent affected their daily interactions with the environment, friends, family and, at the end of the day, their success in school. We were interested in how much they used social networks, at what age they created their profiles, and how free they felt in providing information about themselves and others through the media. According to the results, children create their profiles on social networks at a very early stage, even when they are not ready or educated for it. In addition, children are very open to the virtual world of communication with the people they do not know in real life, even to meet strangers without being aware of possible manipulation, false profiles, violence and the like. There is a clear awareness among most respondents about the need for media education, regardless of the difference in the amount of time that they spend on social networks, as well as a clearly articulated stand on the need to introduce media education as part of compulsory education in schools.
\end{abstract}

Keywords: virtual world, media education, media habits, children and youth, media literacy. 


\section{Literatura:}

Baacke, D. 2007. Medienpädagogik. Tübingen: Niemeyer.

Barlett, J. 2016. Dark Net u digitalnom podzemlju. Beograd: Laguna.

Chayko, M. 2019. Superpovezani: Internet, digitalni mediji i tehno-društveni život. Beograd: Clio, Multimedia.

Dokler, A. 2018. U Finskoj temelje za medijsku pismenost grade već kod djece od 10 mjeseci, [online]. Zagreb: Agencija za elektroničke medije i UNICEF. Dostupno na: https://www.medijskapismenost.hr/u-finskoj-temelje-za-medijsku-pismenostgradimo-vec-kod-djece-od-10-mjeseci/. [12. 6. 2020.]

Društvo za komunikacijsku i medijsku kulturu DKMK. 2017. EU Kids Online. DKMK $s$ partnerima predstavio rezultate prvog nacionalnog komparativnog istraživanja o sigurnosti djece na internetu, [online]. Zagreb: Djeca medija. Dostupno na: https:// www.djecamedija.org/eu-kids-online/ [22. 6. 2020.]

Hobbs, R. 2010. Digital and Media Literacy: A Plan of Action. A White Paper on the Digital and Media Literacy Reccommendations of the Knight Commission of the Information Needs of Communities in a Democracy. Washington: The Aspen Institute.

Hrvatska akademska i istraživačka mreža CARNET. 2018. Integracija digitalne tehnologije u učenje i proučavanje i poslovanje škole, [online]. Zagreb: CARNET. Dostupno na: https://pilot.e-skole.hr/wp-content/uploads/2018/04/Prirucnik_ Integracija-digitalne-tehnologije-u-ucenje-i-poucavanje-i-poslovanje-skole.pdf. [29. 11.2020.]

Katzer, C. 2019. Sajberpsihologija život na mreži: k@ko nas internet menja. Beograd: Laguna.

Klaić, B. 2004. Rječnik stranih riječi. Zagreb: NMH.

Lazić Lasić, J.; Špiranec, S.; Benek Zorica, M. 2012. Izgubljeni u novim obrazovnim okruženjima - pronađeni u informacijskom opismenjivanju. Medijska istraživanja, [online]. 18 (1), str.125-142.

Dostupno na: https://hrcak.srce.hr/index.php?show=toc\&id_broj=6895 [3. 6. 2020.]

Miliša, Z. 2016. Umreženi usamljenici: Zašto nam treba odgoj za medije a ne informatika u nižim razredima pučke škole?, [online]. Zagreb: Portal hrvatskog kulturnog vijeća. Dostupno na: https:/www.hkv.hr/izdvojeno/vai-prilozi/m-o/zlatkomilisa/24890-z-milisa-umrezeni-usamljenici.html [13. 6. 2020.]

Miliša, Z.; Tolić, M.; Vertovšek, N. 2010. Mladi-odgoj za medije, priručnik za stjecanje medijske kompetencije. Zagreb: M.E.P. d.o.o.

Olawale Olaniran, S. 2020. Literacy Library and the Functional Literacy Skills of the 21st Century Adult Learners. Library Philosophy and Practice (e-journal), [online]. 3573, str. 4. Dostupno na: https://digitalcommons.unl.edu/cgi/viewcontent. cgi?article $=6602 \&$ context $=$ libphilprac $[12.1$. 2021.] 
Ruddock, A. 2015. Mladi i mediji. Beograd: Clio, Mulitmedia.

Šućur, Z. 2004. Socijalna isključenost: pojam, pristupi i operacionalizacija. Revija za sociologiju,[online]. 35 (1-2), str. 45-60. Dostupno na: https://hrcak.srce. $\mathrm{hr} / 14459$. [2. 6. 2020.]

Tajić, L. 2013. Medijska pismenost u Bosni i Hercegovini. Sarajevo: Internews.

Turčilo, L. 2020. Medijska pismenost - meta komunikacija za 21. stoljeće. U: Turčilo, L.; Buljubašić; B. ur. Medijska stvarnost: Eseji o korištenju medija u BiH. Sarajevo: Fakultet političkih nauka Univerziteta u Sarajevu. Ch.3., str. 191-200. Dostupno na: http:// fpn.unsa.ba/b/wp-content/uploads/2020/02/MEDIJSKA-STVARNOST-Eseji-okoris\%CC\%8Ctenju-medija-u-BiH_WEB.pdf [12. 6. 2020.]

Vrkić Dimić, J. 2014. Suvremeni oblici pismenosti. Školski vjesnik: časopis za pedagogijsku teoriju i praksu, [online]. 63 (3), str. 381-394. Dostupno u: file://C:/ Documents\%20and\%20Settings/My\%20Documents/Downloads/8_J_Vrkic_ Dimic\%20(3).pdf [14. 6. 2020.]

Zgrabljić Rotar, N. 2007. Suvremeni koncept medijske pismenosti kao dio komunikacijskih znanosti. U: Komunikacijske znanosti. Znanstvene grane $i$ nazivlja. Zagreb: Sveučilište u Zagrebu - Hrvatski studiji, str. 72-85.

Zgrabljić, N.; Erjavec, K. 2000. Odgoj za medije u školama u svijetu: Hrvatski model medijskog odgoja. Medijska istraživanja. 6 (1), str. 89-107. 